\title{
SIMULASI WAKTU TUNGGU MAHASISWA DAN DOSEN DI LAYANAN AKADEMIK UNIVERSITAS BUNDA MULIA
}

\author{
Rudy Santosa Sudirga \\ Manajemen, Universitas Bunda Mulia \\ Alamat surel: rudysudirga@yahoo.com
}

\begin{abstract}
The Management of Academic Service continues to be a major challenge for many college, high school and college organizations in providing better services with fewer resources. The allocation of service staffs and response-time in service involve many challenging issues, because the mean and variance of the response-time in service can be increased dramatically with the intensity of heavy traffic. This study discusses how to use simulation models to improve response time in service operation. Performance at the Academic Service as a whole can be considered very good and is still idle due to utilization of Academic Service, which is still equal to an average of $17 \%$, or it can be said that the workload is not too excessive and deemed to be able to serve the students and lecturers. The performance of Academic Sevice University Bunda Mulia can be considered excellent in terms of operations management, as indicated by the average waiting time, which is very short at only 9.10 seconds.
\end{abstract}

Keywords: Queueing System, Waiting Time, and Simulation

\begin{abstract}
Abstrak
Manajemen Layanan Akademik menjadi tantangan yang besar bagi banyak perguruan tinggi, sekolah tinggi dan organisasi perguruan tinggi dalam memberikan pelayanan yang lebih baik dengan sumber daya yang lebih sedikit. Alokasi staf pelayanan dan waktu respon dalam pelayanan melibatkan banyak tantangan, karena rata-rata waktu pelayanan dan varians dari waktu respon dalam pelayanan dapat meningkat secara dramatis dengan meningkatnya intensitas lalu lintas pelayanan yang padat. Penelitian ini membahas cara menggunakan model simulasi untuk meningkatkan waktu respon dalam operasi pelayanan. Kinerja di Layanan Akademik secara keseluruhan dapat dianggap sangat baik, karena pemanfaatan Layanan Akademik hanya menggunakan waktu dengan rata-rata 17\%, atau dapat dikatakan bahwa beban kerja tidak terlalu berlebihan dan dianggap masih mampu melayani mahasiswa dan dosen dengan baik. Kinerja Layanan Akademik Universitas Bunda Mulia dapat dianggap sangat baik dalam hal manajemen operasi, seperti yang ditunjukkan oleh rata-rata waktu tunggu yang sangat singkat yaitu hanya 9,10 detik.
\end{abstract}

Kata kunci: sistem antrian, waktu tunggu, dan simulasi

\section{PENDAHULUAN}

\section{Latar Belakang}

Manajer bagian Layanan Akademik (LA) akan sangat disibukkan dengan alokasi penempatan staf untuk menjamin agar LA dapat memberikan pelayanan yang terbaik kepada para mahasiswa dan dosen, serta memberikan keputusan yang terbaik pula dari sisi operasional.

Oleh karena itu penulis berkeinginan untuk melakukan penelitian dengan judul Simulasi Waktu Tunggu Mahasiswa Dan Dosen Di Layanan Akademik Universitas Bunda Mulia untuk mengetahui probabilitas waktu tunggu di dalam melayani para mahasiswa dan dosen dengan metode simulasi.

\section{Masalah Penelitian}

Masalah yang dihadapi adalah bagaimana mengevaluasi, apakah sudah terjadi pelayanan yang maksimal dan sangat sibuk di LA Universitas Bunda Mulia seiring dengan bertambahnya mahasiswa Universitas Bunda Mulia setiap tahunnya.

\section{Tujuan Penelitian}

Tujuan penelitian ini untuk mengetahui rata-rata waktu tunggu, probabilitas menunggu, persentase kesibukan, jumlah orang yang menunggu lebih dari waktu tertentu. Bagi LA untuk mengetahui rata-rata jeda waktu datangnya para mahasiswa atau dosen yang ingin mendapatkan pelayanan, rata-rata waktu tunggu mahasiswa dan dosen yang ingin 
mendapatkan pelayanan, dan rata-rata waktu pelayanan bagi mahasiswa dan dosen yang mendapatkan pelayanan.

Tujuan khusus penelitian ini adalah untuk mengetahui apakah perlu dilakukan perubahan kebijakan efektifitas dan efisiensi di Layanan Akademik Universitas Bunda Mulia.

\section{TINJAUAN PUSTAKA}

\section{Rerangka Pemikiran}

Tinjauan Pustaka didasarkan pada beberapa literatur, seperti operations management, management science, dan quantitative analysis for management. Menurut Anderson et al. (2014:607), "a simulation model of a waiting line system where the state of the system, including the number of customers in the waiting line and whether the service facility is busy or idle, changes or evolves over time is referred to as dynamic simulation model".

Jadi simulasi dapat digunakan untuk model antrian, di mana waktu tunggu di sistem mengikuti karakteristik sistem tersebut. Perubahan di sistem antrian tersebut dapat dikategorikan sebagai model simulasi dinamik yang akan di terapkan di penelitian ini.

Menurut Heizer (2014:818-819), "simulation is the attempt to duplicate the features, appearance, and characteristics of a real system, usually via a computerized model".

Model simulasi dapat digunakan untuk menyerupai situasi yang sebenarnya secara matematis. Selain itu dapat menentukan keputusan yang nyata berdasarkan hasil perhitungan simulasi. Dalam penelitian ini penulis juga menggunakan model simulasi dengan perhitungan komputer (computerized simulation model), dengan menggunakan angka random (random number).

Menurut Stevenson dan Ozgur, (2013:724-727), "simulation involves the use of a model that exhibits the important behavioral characteristics of a real system". Simulasi umumnya terdiri dari beberapa langkah:

1. Menentukan masalah yang akan dihitung.
2. Mengumpulkan data.

3. Mengembangkan model simulasi.

4. Melakukan perhitungan simulasi.

5. Menganalisis dan menginterpretasikan hasilnya.

Contoh-contoh persoalan dan penelitian yang dapat dilakukan dan diselesaikan dengan metode simulasi, di antaranya adalah: sistem antrian di automated teller machine, lampu pengatur lalu lintas, ruang tunggu, dan dapat pula digunakan untuk rencana persediaaan dan pengontrolannya di operasi produksi.

Menurut Heizer (2014:819),

keunggulan menggunakan simulasi:

1. Dapat digunakan untuk menganalisis situasi yang nyata dan kompleks yang tidak dapat diselesaikan dengan cara konvensional.

2. Simulasi dapat digunakan untuk semua bentuk distribusi probabilitas, tidak harus berdistribusi normal.

3. Dapat digunakan untuk waktu yang akan datang atau panjang misalnya setahun, karena dapat menggunakan perhitungan simulasi komputer dalam waktu yang singkat.

4. Jika terjadi perubahan, maka model simulasi dapat menjawab pertanyaan seperti "what-if?", karena dapat diselesaikan dengan simulasi komputer dalam beberapa menit.

5. Simulasi tidak mengganggu atau menghambat pekerjaaan yang terjadi di dunia nyata, seperti misalnya eksperimen yang dilakukan untuk menetapkan kebijakan baru di rumah sakit atau di pabrik.

Menurut Heizer (2014:819),

keterbatasan menggunakan simulasi:

1. Model simulasi yang baik dapat membutuhkan waktu yang lama untuk dikembangkan.

2. Simulasi tidak menghasilkan suatu keadaan optimal, akan tetapi umumnya memberikan solusi yang mendekati titik optimal.

3. Simulasi harus menggunakan kondisi dan data yang tepat, karena tanpa ketepatan kondisi yang diteliti dan data yang tepat, model simulasi tidak akan 
menghasilkan jawaban yang realistik dan cukup baik.

4. Model simulasi adalah sangat unik dan hasilnya tidak dapat digunakan untuk masalah yang lain yang kondisinya berbeda.

\section{Disain Penelitian}

Dalam penelitian ini akan diambil data mengenai pelayanan di LA, di antaranya adalah: waktu jeda kedatangan (interarrival time) yang paling minimal, waktu jeda kedatangan yang paling maksimal, rata-rata waktu pelayanan (service time), dan standard deviasi waktu pelayanan. Penelitian ini menggunakan model simulasi dinamik (dynamic simulation model).

\section{METODE PENELITIAN}

\section{Rancangan Penelitian}

Penelitian ini menggunakan metode simulasi yang dipelajari di mata kuliah operations management, management science, dan quantitative analysis for management.

Menurut Anderson et al. (2014:619) dan Render et al. (2015:489), metode simulasi dipilih karena metode simulasi mempunyai beberapa keunggulan sebagai berikut:

- Simulasi dapat digunakan untuk mempelajari dan menganalisis suatu sistem yang kompleks dan sulit di kehidupan yang nyata.

- Model simulasi memberikan kemudahan di dalam melakukan eksperimen untuk suatu sistem yang nyata.

- Simulasi memungkinkan untuk mempelajari efek yang saling mempengaruhi antara suatu komponen atau peubah dan dapat digunakan untuk menentukan peubah mana yang paling penting.

Sebagai contoh, beberapa model antrian (queuing model) membutuhkan penyelesaian dengan Poisson Distribution sedangkan beberapa inventory model dan network model membutuhkan normality data atau data yang terdistribusi normal. Tetapi simulasi dapat digunakan dengan semua distribusi probabilitas dan tidak membutuhkan pola distribusi yang khusus.

Menurut Anderson et al. (2014:619) dan Render et al. (2015:490), metode simulasi juga mempunyai beberapa keterbatasan sebagai berikut:

- Simulasi tidak menghasilkan suatu solusi yang optimal terhadap suatu permasalahan bila dibandingkan dengan metode analisis kuantitatif yang lainnya, seperti economic order quantity, linear programming atau PERT, akan tetapi selalu menghasilkan solusi yang mendekati optimal.

Menurut Krajewksi et al. (2013:256), "Waiting Lines and Simulation", "the arrivals had a Poisson distribution (or exponential interarrival times), the service times had an exponential distribution, the service facilities had a simple arrangement, the waiting line was unlimited, and the priority discipline was first-come, first-served. Simulation waitingline theory has been used to develop other models in which these criteria are not met, but these models are complex".

\section{Populasi dan Sampel}

Di dalam penelitian ini diambil sampel sebanyak 150 orang yang terdiri baik dari mahasiswa atau dosen yang dilayani oleh bagian LA.

\section{Instrumen Penelitian}

Metode simulasi dipilih karena simulasi merupakan salah satu teknik manajemen operasional yang dapat digunakan untuk menganalisis suatu keadaan dan tingkah laku dari suatu sistem antrian dalam rentang intensitas trafik yang sangat teratur (normal distribution), cukup teratur (uniform distribution), atau tidak teratur (random distribution) yang mewakili sistem yang nyata (the real-world system).

\section{Pengumpulan Data}

Pengambilan data dilakukan oleh penulis di LA pada saat kuliah semester genap 2015/2016. Penulis mengambil data sebanyak 150 orang di bulan April 2016 dan 150 orang lagi di bulan Mei 2016, yang terdiri baik dari mahasiswa atau dosen. 
Menurut Anderson et al. (2014:610):

Gambar 3.1 menunjukkan urut-urutan operasi secara logika dan matematika yang dibutuhkan untuk melakukan simulasi

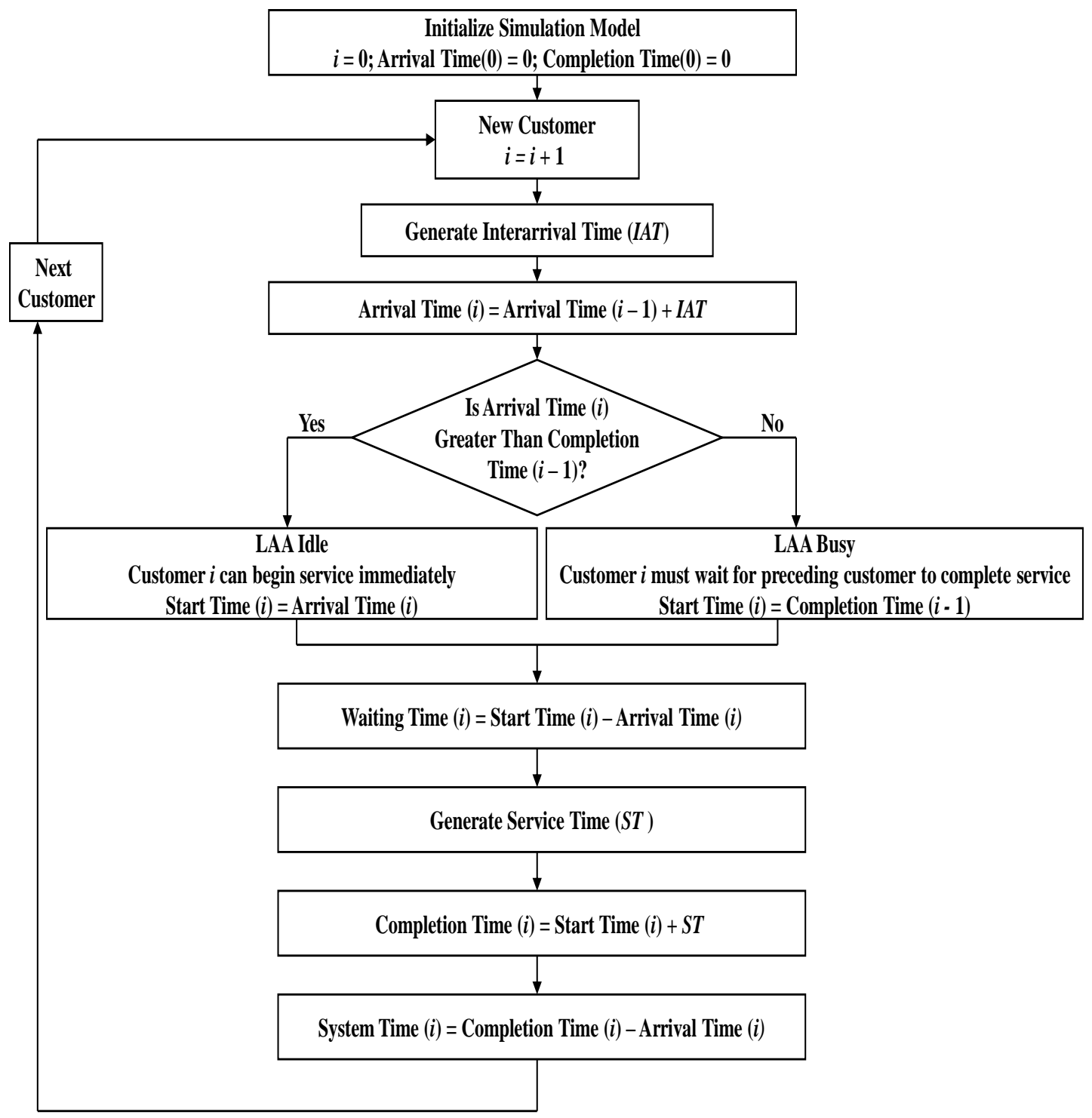

Sumber: Anderson et al. (2104:611)

Gambar 1 Flowchart for Waiting Line Simulation 
Menurut Anderson et al. (2014:610): Tabel 3.1 menunjukkan contoh perhitungan secara manual dari 10 pelanggan yang dilayani untuk mengilustrasikan logika model simulasi dan untuk menunjukkan bagaimana data penelitian simulasi dapat dikembangkan untuk perhitungan simulasi.

Tabel 1. Contoh Simulasi

\begin{tabular}{cccccccc}
\hline Pelanggan & $\begin{array}{c}\text { Waktu Jeda } \\
\text { Kedatangan }\end{array}$ & $\begin{array}{c}\text { Waktu } \\
\text { Kedatangan }\end{array}$ & $\begin{array}{c}\text { Waktu } \\
\text { Mulai }\end{array}$ & $\begin{array}{c}\text { Waktu } \\
\text { Tunggu }\end{array}$ & $\begin{array}{c}\text { Waktu } \\
\text { Pelayanan }\end{array}$ & $\begin{array}{c}\text { Waktu } \\
\text { Selesai }\end{array}$ & $\begin{array}{c}\text { Waktu } \\
\text { di Sistem }\end{array}$ \\
\hline & & & & & & & \\
2 & 1,4 & 1,4 & 1,4 & 0,0 & 2,3 & 3,7 & 2,3 \\
3 & 1,3 & 2,7 & 3,7 & 1,0 & 1,5 & 5,2 & 2,5 \\
4 & 4,9 & 7,6 & 7,6 & 0,0 & 2,2 & 9,8 & 2,2 \\
5 & 3,5 & 11,1 & 11,1 & 0,0 & 2,5 & 13,6 & 2,5 \\
6 & 0,7 & 11,8 & 13,6 & 1,8 & 1,8 & 15,4 & 3,6 \\
7 & 2,8 & 14,6 & 15,4 & 0,8 & 2,4 & 17,8 & 3,2 \\
8 & 2,1 & 16,7 & 17,8 & 1,1 & 2,1 & 19,9 & 3,2 \\
9 & 0,6 & 17,3 & 19,9 & 2,6 & 1,8 & 21,7 & 4,4 \\
10 & 2,5 & 19,8 & 21,7 & 1,9 & 2,0 & 23,7 & 3,9 \\
\hline Total & 1,9 & 21,7 & 23,7 & 2,0 & 2,3 & 26,0 & 4,3 \\
\hline Rata-Rata & 21,70 & & \multicolumn{7}{c}{11,20} & 20,90 & & 32,10 \\
\hline
\end{tabular}

Sumber: Anderson et al. (2104:612)

Pelanggan 1:

Waktu jeda kedatangan $=1,4$ menit akan dihasilkan dengan simulasi. Oleh karena simulasi mulai dari 0 , maka waktu kedatangan pelanggan $=0+1,4=1,4$ menit, Pelanggan 1 akan segera mendapatkan pelayanan, dengan waktu mulai $=1,4$ menit, Waktu tunggu pelanggan $1=$ waktu mulai waktu kedatangan $=1,4-1,4=0$ menit,

Waktu pelayanan $=2,3$ menit akan dihasilkan dengan simulasi.

Waktu selesai pelanggan $1=$ waktu mulai + waktu pelayanan $=1,4+2,3=3,7$ menit.

Waktu di sistem untuk pelanggan $1=$ waktu selesai - waktu kedatangan $=3,7-1,4=2,3$ menit.

Pelanggan 2:

Waktu jeda kedatangan $=1,3$ menit akan dihasilkan dengan simulasi.

Oleh karena waktu kedatangan pelanggan 1 $=1,4$, maka waktu kedatangan pelanggan 2 $=1,4+1,3=2,7$ menit.

Oleh karena pelanggan 1 baru selesai dalam waktu 3,7 menit, dan karena waktu kedatangan pelanggan $2=2,7$ menit, maka pelanggan 2 akan mendapatkan pelayanan pada 3,7 menit, yang merupakan waktu mulai untuk pelanggan.

Waktu tunggu pelanggan $2=$ waktu mulai waktu kedatangan $=3,7-2,7=1$ menit,

Waktu pelayanan $=1,5$ menit akan dihasilkan dengan simulasi.

Waktu selesai pelanggan $2=$ waktu mulai + waktu pelayanan $=3,7+1,5=5,2$ menit.

Waktu di sistem untuk pelanggan $2=$ waktu selesai - waktu kedatangan $=5,2-2,7=2,5$ menit.

\section{Pelanggan 3:}

Waktu jeda kedatangan $=4,9$ menit akan dihasilkan dengan simulasi.

Oleh karena waktu kedatangan pelanggan 2 $=2,7$, maka waktu kedatangan pelanggan 3 $=2,7+4,9=7,6$ menit.

Oleh karena pelanggan 2 sudah selesai dalam waktu 5,2 menit, dan karena waktu kedatangan pelanggan $3=7,6$ menit, maka pelanggan 3 akan segera mendapatkan pelayanan, dengan waktu mulai $=7,6$ menit Waktu tunggu pelanggan $3=$ waktu mulai waktu kedatangan $=7,6-7,6=0$ menit. 
Waktu pelayanan $=2,2$ menit akan dihasilkan dengan simulasi.Waktu selesai pelanggan $3=$ waktu mulai + waktu pelayanan $=7,6+2,2=9,8$ menit. Waktu di sistem untuk pelanggan $3=$ waktu selesai waktu kedatangan $=9,8-7,6=2,2$ menit.

Menurut Anderson et al. (2014:616):

Tabel 3.2 dan Tabel 3.3 adalah suatu lembar kerja Excel yang digunakan untuk melakukan perhitungan simulasi untuk 1000 pelanggan yang berasal dari data primer penelitian sebanyak 150 pelanggan. Tabel 3.2 adalah perhitungan simulasi dengan data penelitian pada bulan April 2016, sedangkan Tabel 3.3 adalah perhitungan simulasi dengan data penelitian pada bulan Mei 2016.

\section{Analisis Data}

Tabel 2. Simulasi April 2016

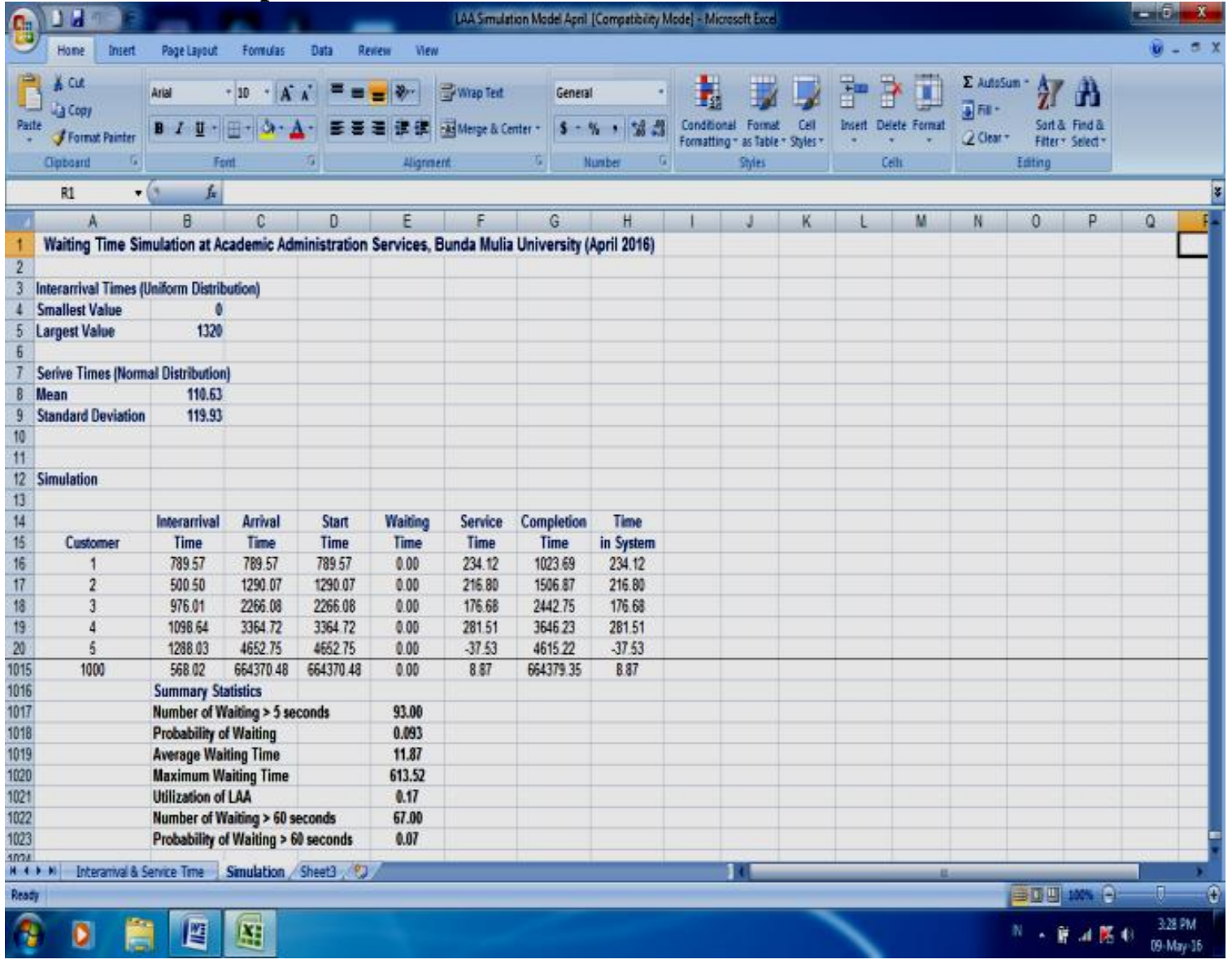


Tabel 3. Simulasi Mei 2016

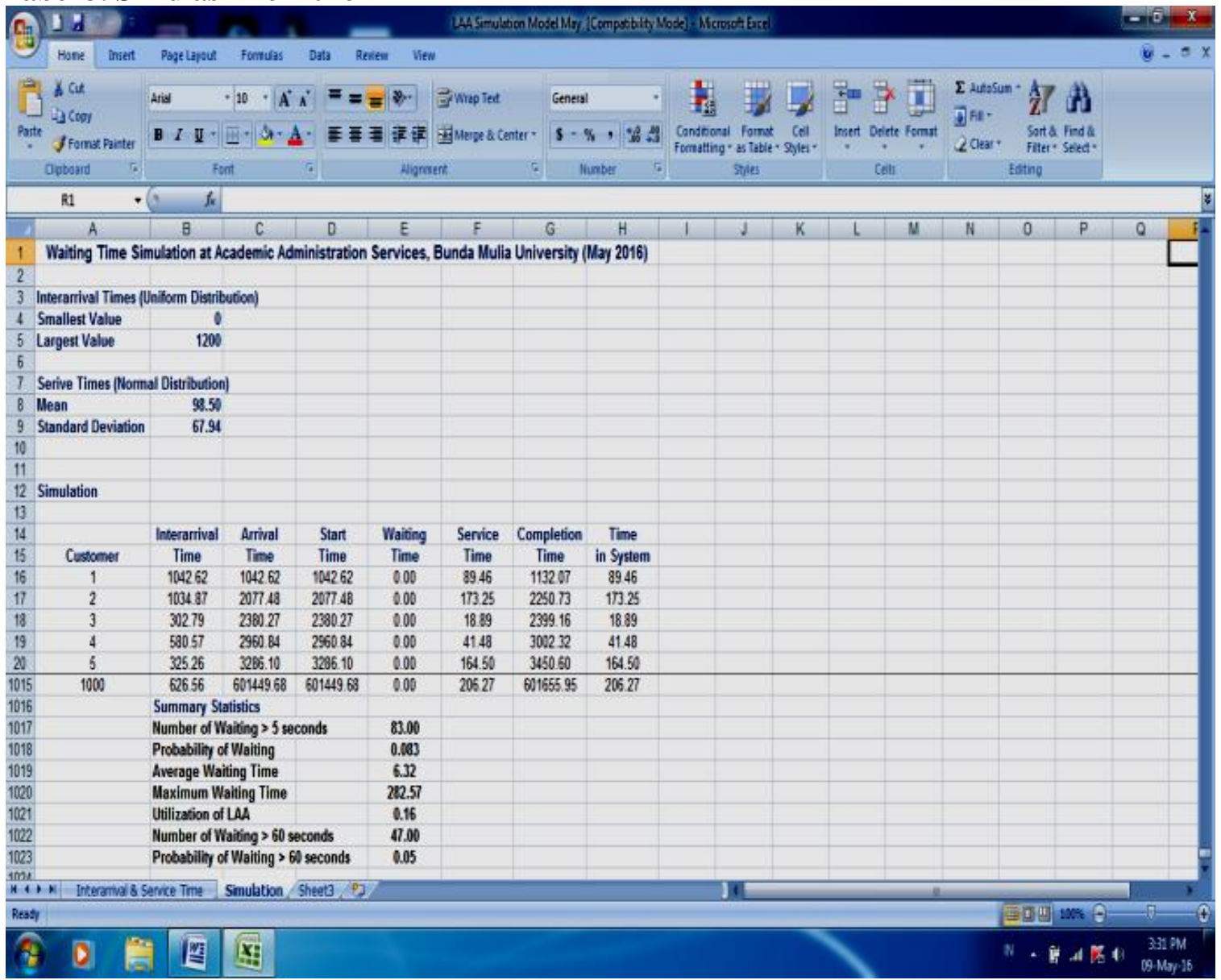

Anderson et al. (2014:638-640): We simulated the operation of waiting line system for 1000 customers. The interarrival times are described by a uniform distribution with a smallest time (cell B4) and a largest time (cell B5). A normal probability distribution with a mean (cell B8) and a standard deviation (cell B9) describes the service time distribution. Simulation information for the first customer appears in row 16 of the worksheet. The cell formulas for row 16 are as follows:

Cell A16

customer

Cell B16

Cell C16

\section{Enter 1 for the first}

Simulate the interarrival time for customer 1 (uniform distribution) $=\$ B \$ 4+R A N D() * \$ B \$ 5$. $\$ B \$ 4)$

Compute the arrival time for customer $1=B 16$
Cell D16

Compute the start time for customer $1=$ C16

Cell E16 Compute the waiting time for customer $1=D 1-C 16$

Cell F16 Simulate the service time for customer 1 (normal distribution) $=N O R M I N V(R A N D(), \$ B \$ 8$, $\$ B \$ 9)$

Cell G16 Compute the completion time for customer $1=D 16+$ F16

Cell H16 Compute the time in the system for customer $1=G 16$ $-C 16$

Simulation information for the second customer appears in row 17 of the worksheet. The cell formulas for row 17 are as follows:

Cell A17 Enter 2 for the second customer 
Cell B17

Simulate the interarrival

time for customer 2

(uniform distribution)

$=\$ B \$ 4+R A N D() *(\$ B \$ 5-$

$\$ B \$ 4)$

Cell C17 Compute the arrival time for

customer $2=C 16+B 17$

Cell D17 Compute the start time for

customer 2

$=I F(C 17>G 16, C 17, G 16)$

Cell E17 Compute the waiting time

for customer $2=D 17-C 17$

Cell F17 Simulate the service time for customer 2 (normal

distribution)

$=N O R M I N V(R A N D(), \$ B \$ 8$,

$\$ B \$ 9)$

Cell G17 Compute the completion

time for customer $2=D 17+$ F17

Cell H17 Compute the time in the system for customer $2=$ G17 $-C 17$

Cells A17:H17 can be copied to cells A1015:H1015 in order to provide the 1000-customer simulation.

Ultimately, summary statistics will be collected in order to describe the results of 1000 customers. The following Excel formulas provided the summary statistics. Cell E1017 Number of customers who had to wait for more than 5 seconds

5")

$=$ COUNTIF $\left(E 16: E 1015,{ }^{\prime}>\right.$

Cell E1018 Probability of waiting $=E 1017 / 1000$

Cell E1019 The average waiting time $=A V E R A G E(E 16: E 1015)$

Cell E1020 The maximum waiting time $=M A X(E 16: E 1015)$

Cell 1021 The utilization of LAA $=S U M(F 16: F 1015) /(G 1015$ G16)

Cell 1022 The number of customers who had to wait for more than 60

seconds $=$ COUNTIF $($ E16:E1 $015, ">60 ")$

Cell 1023 Probability of waiting for more than 60 seconds $=E 1022 / 1000$

\section{HASIL DAN PEMBAHASAN}

Menurut Anderson et al. (2014:617), dari 150 data primer hasil penelitian, dapat ditentukan rata-rata dan standar deviasi waktu pelayanan, setelah itu baru dilakukan perhitungan simulasi untuk 1000 pelanggan dengan menggunakan bantuan lembar kerja Excel, seperti yang dapat di lihat di Tabel 3.2 dan Tabel 3.3. Dari perhitungan simulasi ini dapat disimpulkan bahwa:

- Jumlah yang menunggu > 5 detik dalam simulasi ini adalah 87 orang.

- Probabilitas waktu menunggu adalah kecil yaitu $8.7 \%$.

- Rata-rata waktu menunggu adalah rendah yaitu 9.10 detik.

- Waktu menunggu maksimal juga relatif kecil yaitu 375.03 detik.

- $\quad$ Kinerja LA juga belum maksimal yaitu rata-rata $17 \%$.

- Jumlah yang menunggu > 60 detik kemungkinannya ada 60 orang.

- Probabilitas menunggu $>60$ detik juga kecil yaitu $6 \%$.

Di sini jelas terlihat bahwa baik mahasiswa atau dosen Universitas Bunda Mulia masih dapat terlayani dengan baik. Karena yang menunggu > 5 detik dalam simulasi 1000 data simulasi hanya terjadi 87 kali atau relatif kecil. Probabilitas waktu menunggu tersebut juga kecil yaitu hanya $8.7 \%$, sedangkan rata-rata waktu menunggu adalah sangat kecil yaitu hanya 9.10 detik. Waktu menunggu maksimal juga relatif kecil yaitu 375.03 detik. Jumlah yang menunggu $>60$ detik kemungkinannya ada 60 orang dan probabilitas waktu menunggu $>60$ detik juga kecil kemungkinannya yaitu hanya $6 \%$.

\section{SIMPULAN DAN SARAN}

Kinerja di bagian LA secara keseluruhan dapat dianggap sangat baik dan masih banyak waktu terluang serta belum maksimal yaitu sebesar rata-rata $17 \%$. Dapat dikatakan bahwa beban kerja di bagian LAA tidaklah terlalu berlebihan dan dianggap masih dapat dengan baik dan layak melayani para mahasiswa dan dosen Universitas Bunda Mulia. Dapat disimpulkan bahwa 
kinerja di bagian LA dapat dianggap sangat baik ditinjau dari sisi manajemen operasional, karena beban pekerjaan tidaklah terlalu berlebihan. Secara keseluruhan dapat dikatakan bahwa tidaklah terjadi suatu pelayanan yang dianggap tidak memuaskan baik kepada mahasiswa atau kepada dosen Universitas Bunda Mulia. Bagian pelayanan dapat dengan sigap melayani dengan segera permintaan pelayanan yang ditunjukkan dengan rata-rata waktu menunggu adalah sangat kecil, yaitu hanya 9.10 detik.

Dapat disarankan bahwa tidaklah perlu dilakukan perubahan efektivitas dan efisiensi di Layanan Akademik Universitas Bunda Mulia.

Saran lain yang perlu penulis berikan di sini adalah jika dipandang dari sisi manajemen operasional, maka yang paling efektif adalah tempat pelayanan haruslah berbentuk huruf $U$ atau setengah lingkaran agar dapat melayani para mahasiswa dan dosen secara lebih ergonomics, efektif dan efisien.

Saran lainnya adalah agar para petugas pelayanan di bagian LA tidak duduk di satu tempat yang berdekatan atau mengumpul menjadi satu akan tetapi haruslah duduk secara berderet membentuk huruf $U$ atau setengah lingkaran agar dapat melayani para mahasiswa dan dosen secara lebih ergonomics, efektif dan efisien.

Jika suatu saat tertentu di mana pelayanan LA dalam kondisi yang sedang ramai, misalnya saat ujian, penulis menyarankan:

- $\quad$ Untuk menambah 1 orang karyawan di bagian LA, misalnya dengan penugasan khusus atau dibayar khusus. Tetapi sebelum menambah karyawan yang bertugas di bagian LA, perlu dilihat dahulu apakah hasil perhitungan simulasi di bagian LA sudah sangat sibuk, misalnya sudah mendekati di atas $60 \%$ ?

- Disain tempat di bagian LA sebaiknya di ubah menjadi bentuk $U$, sesuai dengan prinsip manajemen operasional di mana bentuk $U$ akan lebih efektif dan efisien di dalam menangani pelayanan.

- Gambar bentuk U dalam manajemen operasional adalah sebagai berikut:

Menurut Heizer (2014:407):

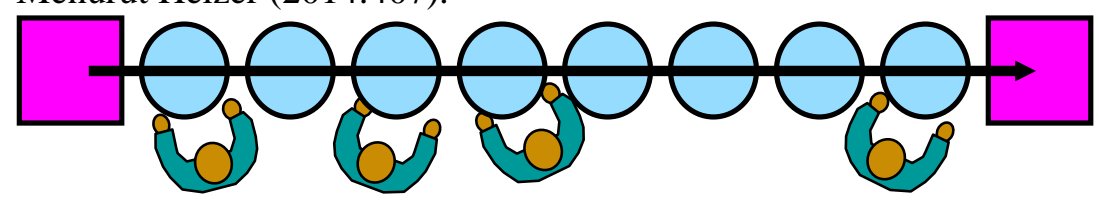

Sumber: Heizer (2014:407)

Gambar 2. Straight Line Worker

Tata Ruang sekarang - lurus sehingga sangat sulit untuk membagi pekerjaan sama banyak
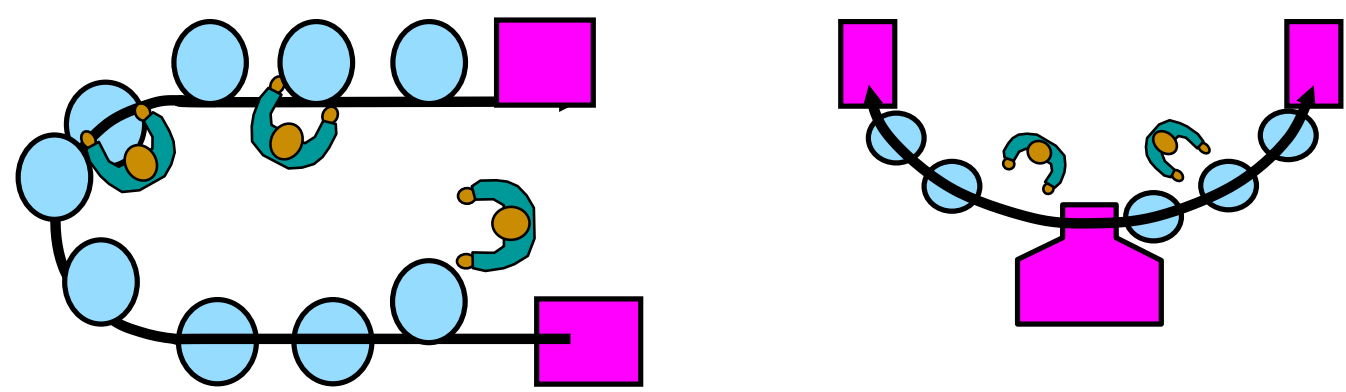

Sumber: Heizer (2014:407)

Gambar 3. U Shape Worker 
Tata Ruang yang lebih baik dalam bentuk huruf $\mathrm{U}$, sehingga pekerja lebih baik dalam menangani pelayanan. Empat pekerja dapat dikurangi menjadi tiga saja.

Tata ruang yang lebih baik, pekerja dapat saling membantu satu sama lain. Masih dapat ditambah pekerja menjadi tiga jika beban pekerjaan bertambah. Tata ruang bentuk huruf $U$ juga mengurangi luas kebutuhan tata ruang yang sebenarnya, meningkatkan komunikasi, mengurangi jumlah tenaga kerja, dan inspeksi pengontrolan lebih mudah dilakukan.

Dengan kata lain, bahwa disain tata ruang dengan bentuk huruf $U$ akan mengurangi pergerakan karyawan dan tempat pelayanan yang dibutuhkan. Selain itu dapat meningkatkan komunikasi pelayanan, dapat pula mengurangi jumlah karyawan di bagian pelayanan, dan dapat memfasilitasi pemeriksaan kebutuhan akan pelayanan dengan lebih baik.

Jadi dapat dikatakan fasilitas pelayanan akan menjadi lebih produktif, efektif dan efisien.

\section{DAFTAR PUSTAKA}

Anderson, D.R., et al., 2014. An Introduction to Management Science, Quantitative Approaches to Decision Making $\left(14^{\text {th }}\right.$ ed.). South-Western, a division of Thomson Learning.

Balakrishnan, N., Render, B., Stair, R.M., 2007. Managerial Decision Modeling with Spreadsheets $\left(2^{\text {nd }}\right.$ ed.). Pearson Education, Inc., Upper Saddle River, New Jersey.

Heizer, J., Render, B., 2014. Operations Management (11 ${ }^{\text {th }}$ ed.). Pearson Education Limited, USA.

Hillier, F.S. et al., 2008. Introduction to Management Science $\left(3^{\text {rd }}\right.$ ed.). McGraw-Hill/Irwin, New York.

Krajewski, L.J. et al., 2013. Operations Management Processes and Supply Chains $\left(10^{\text {th }}\right.$ ed.). Pearson Education Limited, USA.

Law, Averill., 2007. Simulation Modeling and Analysis with Expertfit Software
( $4^{\text {th }}$ ed.). McGraw-Hill/Irwin, New York.

Render, B., Stair, R.M., Hanna, M.E., 2015. Quantitative Analysis for Management $\left(12^{\text {th }}\right.$ ed.). Pearson Education Limited, USA.

Stevenson, W.J., 2012. Operations Management (11 ${ }^{\text {th }}$ ed.). McGrawHill/Irwin, New York.

Stevenson, W.J., Ozgur, C., 2013. Introduction to Management Science with Spreadsheets ( $3^{\text {th }}$ ed.). McGrawHill/Irwin, New York.

Taylor, B.W., 2013. Introduction to Management Science (11 ${ }^{\text {th }}$ ed.). Pearson Education, Inc., Upper Saddle River, New Jersey.

Waters, Donald., 2008. Quantitative Methods for Business (4 ${ }^{\text {th }}$ ed.). Pearson Education, Inc., Upper Saddle River, New Jersey.

Winston, W.L., Albright, S.C., 2007. Practical Management Science $\left(3^{\text {rd }}\right.$ ed.). South-Western, a division of Thomson Learning.

Wisniewski, Mik., 2009. Quantitative Methods for Decision Makers $\left(5^{\text {th }}\right.$ ed.). Pearson Education, Inc., Upper Saddle River, New Jersey. 